\title{
A unique case of isolated sebaceous adenoma of the bulbar conjunctiva
}

\author{
Um caso único de adenoma sebáceo isolado de conjuntiva bulbar
}

Hatice Deniz Ilman ${ }^{1}$, Elif Betul Turkoglu¹, Ahmet Burak Bilgin ${ }^{1}$, Ibrahim Bassorgun², M. Erkan Dogan ${ }^{1}$, Mustafa Unal ${ }^{1}$

\begin{abstract}
Our patient was a 34 year-old male who presented with a painless conjunctival mass that had developed 3 months before his first visit. On performing slit-lamp biomicroscopy, a lobulated pink-yellowish solid mobile mass was observed on the nasal bulbar conjunctival surface of his left eye. The tumor was excised, and histopathologic examination of the tumor revealed a sebaceous adenoma. Systemic examination was normal. No recurrence was observed during the 24-month follow-up period. Sebaceous adenoma of the bulbar conjunctiva is an extremely rare benign tumor, which may be observed to be isolated in the absence of malignancy.
\end{abstract}

Keywords: Adenoma/pathology; Adenoma/surgery; Conjunctival neoplasms/surgery; Adenocarcinoma, sebaceous/pathology

\section{RESUMO}

Nosso paciente era um homem de 34 anos que apresentou uma massa conjuntival indolor desde há 3 meses antes da primeira consulta. Na biomicroscopia por lâmpada de fenda, observa-se uma massa rosa-amarelada, sólida, móvel e lobulada na superfície conjuntival bulbar nasal, em seu olho esquerdo. O tumor foi retirado e o exame histopatológico demonstrou um adenoma sebáceo. O exame sistêmico era normal. Nenhuma recidiva foi observada durante os 24 meses de acompanhamento. Adenoma sebáceo da conjuntiva bulbar é um tumor benigno extremamente raro e pode servisto isolado, sem quaisquer doenças malignas associadas.

Descritores: Adenoma/patologia; Adenoma/cirurgia; Neoplasias da túnica conjuntiva/cirurgia; Adenocarcinoma sebáceo/patologia

\section{INTRODUCTION}

Sebaceous proliferations such as sebaceous hyperplasia and sebaceous adenoma, which mainly present after the age of 60 years, typically arise in the head and neck ${ }^{(1)}$. Sebaceous adenomas were first reported in 1949 and characterized as benign skin tumors presenting as pink or yellow nodules approximately $5 \mathrm{~mm}$ in size ${ }^{(2)}$. Sebaceous adenomas rarely develop in the conjunctiva and are mainly encountered on the caruncle ${ }^{(3,4)}$. As an example of another rare localization, sebaceous adenoma of the palpebral conjunctiva combined with atypical adenomatous hyperplasia of the endometrium was reported in a 42-year-old female(5). Bulbar conjunctiva was reported in only one case in association with a multiple malignancy syndrome called Muir-Torre syndrome ${ }^{(6)}$. We aimed to report a unique sebaceous adenoma primarily located at the nasal bulbar conjunctiva in an adult in the absence of systemic malignancy.

\section{CASE REPORT}

A 34-year-old male presented with a solid mobile mass that had developed three months before his first visit. There was no evidence of trauma or infection. A lobulated pink-yellowish, richly vascularized lesion on the surface of the nasal side of the bulbar conjunctiva in his left eye, measuring $7 \times 11 \mathrm{~mm}$ in size, was detected on performing slit-lamp biomicroscopic examination. The anterior margin of the mass was superonasally located, $7 \mathrm{~mm}$ away from the limbus, and it posteriorly and nasally extended through the caruncle; however, the nasal margin of the mass did not pass the plica semilunaris (Figure 1). On ocular examination, best-corrected visual acuity was 20/20 in both eyes. The tarsal and fornical conjunctival surface and caruncles were normal. The remaining ophthalmic examination was noncontributory. Because of recent enlargement and cosmetic concerns, the tumor with a 2-mm strip of normal-appearing conjunction was excised under the presumptive diagnosis of papilloma. The margin of the excised lesion was tumor-negative. A subconjunctival tumor with enlarged and lobulated sebaceous glands consisting of well-differentiated cells with low mitotic activity $\left(1 \mathrm{mitosis} / \mathrm{mm}^{2}\right)$ was identified, and no atypia was observed on histopathological examination (Figure 2); sebaceous adenoma was diagnosed. Because of the unusual diagnosis and localization, a further work-up was offered for detecting any possible malignancies. Systemic examinations, blood tests, and radiological examinations were performed. There was no history of malignancy in the family. The patient has been followed up for 24 months. There were no malignancies and recurrence of the lesion in the excised area.

\section{DISCUSSION}

The meibomian glands and glands of Zeiss are sebaceous glands in the eyelids, and the brow cilia and the caruncle are other areas in which sebaceous glands are located. However, normally, sebaceous glands are not present in the conjunctiva ${ }^{(3,4,6,7)}$. In the present case, the tumor was present on the bulbar conjunctiva with no connection to the caruncle.

It is unclear how a tumor of sebaceous origin can primarily form on the bulbar conjunctiva. There may have been a faulty migration of sebaceous gland cells from the caruncle through the nasal bulbar
Submitted for publication: June 30, 2014

Accepted for publication: August 31, 2015

Department of Ophthalmology, Akdeniz University, Antalya, Turkey.

2 Department of Pathology, Akdeniz University, Antalya, Turkey.
Funding: No specific financial support was available for this study.

Disclosure of potential conflicts of interest: None of the authors have any potential conflict of interest to disclose.

Corresponding author: Elif Betul Turkoglu. Akdeniz Universitesi Hastanesi, Goz Hastaliklari A.D. Dumlupinar Blv, 07058 - Antalya - Turkey - E-mail: drelifbetul@yahoo.com 


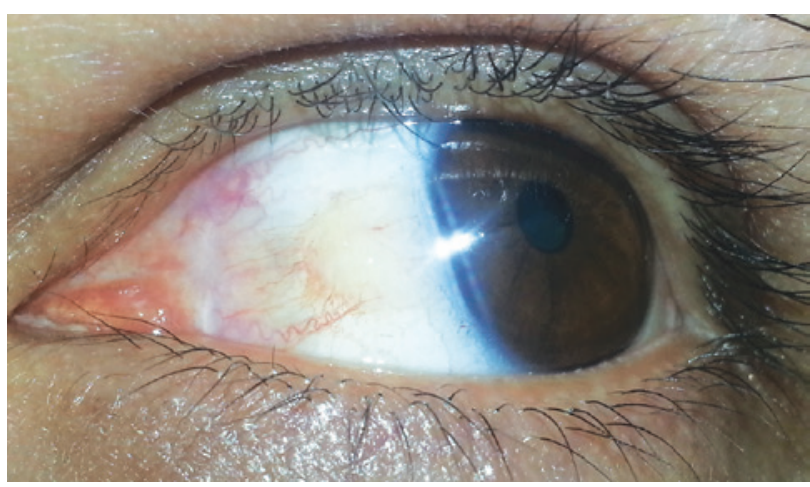

Figure 1. Yellow-pinkish lobulated vascularized tumor with a gel-like appearance lying on the surface of the bulbar conjunctiva was clearly observed during down gaze.

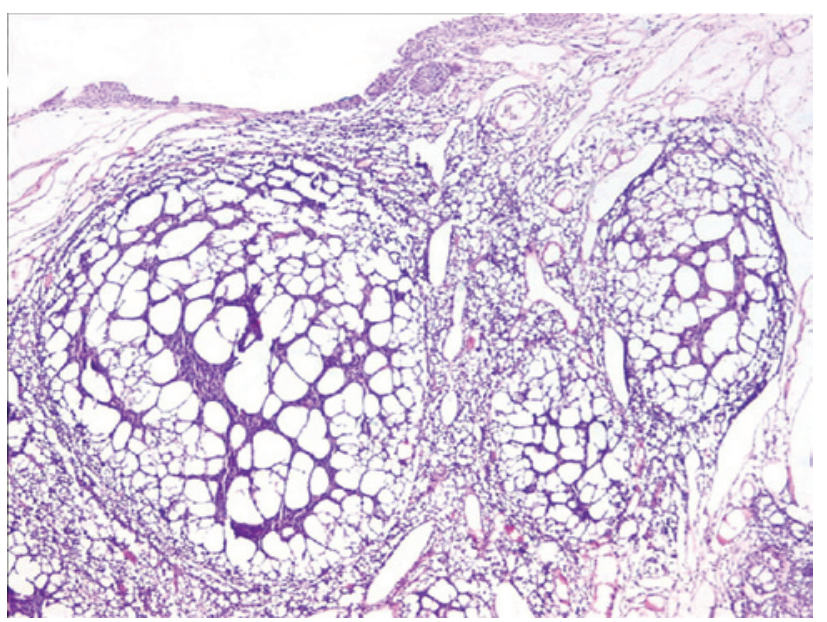

Figure 2. Lobulated sebaceous adenoma is observed under the conjunctival epithelium. Tumor nodules were composed of mature sebocytes. Tumor cells had no mitotic activity and there was no evidence of atypia. (hematoxylin-eosin; original magnification, $\times 400)$. conjunctiva or it may have derived from pluripotent basal cells of the conjunctival epithelium.

The best-known association between sebaceous tumors including sebaceous hyperplasia, adenoma or carcinoma, and visceral malignancy is represented by the Muir-Torre syndrome. Previously recorded cases associated with the Muir-Torre syndrome were located on the eyelids, palpebral conjunctiva, or caruncle, except for a single case located at the bulbar conjunctiva associated with glioblastoma multiforme and chronic lymphocytic leukemia ${ }^{(8)}$. Our patient was examined for any potential malignancies; however, all systemic examinations were normal. No recurrence of the lesion or other malignancies was found at the 2-year follow-up. With regard to the risk of potential malignancy, we have decided to continue annual examination of the patient.

To the best of our knowledge, this case is the first isolated sebaceous adenoma of the bulbar conjunctiva in the absence of systemic malignancy. A vast majority of benign and malign lesions from ectodermal, mesodermal, and endodermal origins can be detected in the presence of primary conjunctival tumors. Furthermore, sebaceous adenoma should be considered in the diagnosis of benign conjunctival tumors, and histopathologic evaluation must be performed to reach a definite diagnosis.

\section{REFERENCES}

1. Deprez M, Uffer S. Clinicopathological features of eyelid skin tumors. A retrospective study of 5504 cases and review of literature. Am J Dermatopathol. 2009;31(3):256-62.

2. VanWalbeek K. Adenoma of a sebaceous gland of the lacrimal caruncle. Ophthalmologica 1949;117(6):370

3. Shields CL, Shields JA. Tumors of the conjunctiva and cornea. Surv Ophthalmol. 2004 49(1):3-24.

4. Shields JA, Demirci H, Marr BP, Eagle RC Jr, Stefanyszyn M, Shields CL. Conjunctival epithelial involvement by eyelid sebaceous gland carcinoma. The $2003 \mathrm{~J}$. Howard Stokes lecture. Ophthal Plast Reconstr Surg. 2005;21(2):92-6.

5. Grossniklaus HE, Gren WR, Luckenbach M, Chan CC. Conjunctival lesions in adults. A clinical and histopathological review. Cornea. 1987;6(2):78-116.

6. Meier-Gibbons F, Messmer E. Sebaceous gland adenoma of the palpebral conjunctiva in a patient with Muir-Torre-syndrome: a case report. Graefes Arch Clin Exp Ophthalmol. 1994;232(12):734-6.

7. Apple DJ, Rabb MF. Ocular pathology. clinical applications and self assesment. $4^{\text {th }}$ ed St. Louis: Mosby-Year Book; 1991.

8. Kiratli H, Poyraz C, Gököz A. Sebaceous adenoma of the bulbar conjunctiva in association with glioblastoma multiforme and chronic lymphocytic leukemia. Cornea. 2007; 26(9):1136-7. 